\title{
NIOSH Skin Notation Profiles Aldrin
}
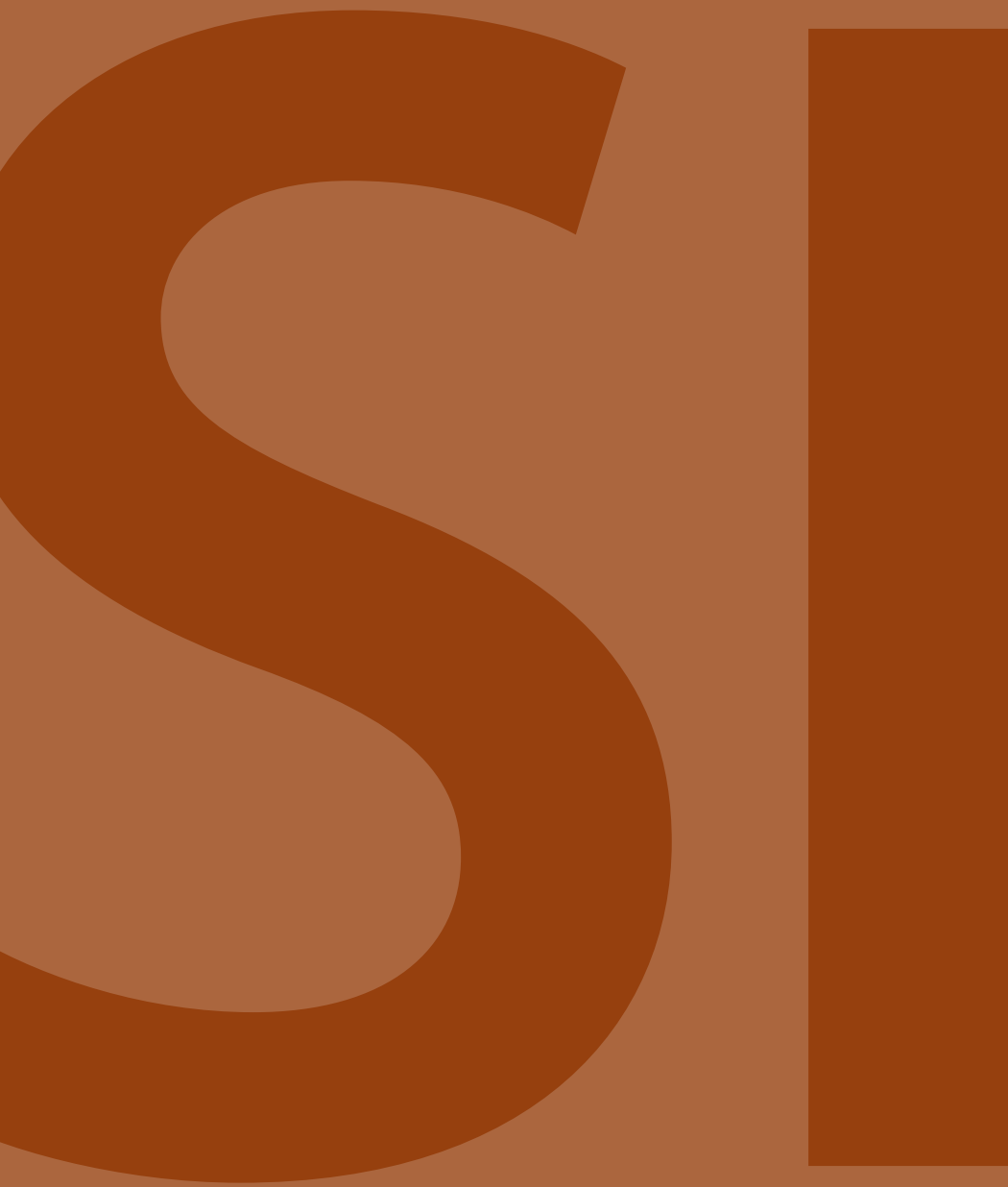

$\mathrm{ID}^{\mathrm{SK}}$

$[S K]$

SYS

SYS (FATAL)

DIR

DIR (IRR)

DIR (COR)

DEPARTMENT OF HEALTH AND HUMAN SERVICES

Centers for Disease Control and Prevention

National Institute for Occupational Safety and Health 
This page intentionally left blank. 


\title{
NIOSH Skin Notation (SK) Profile
}

\author{
Aldrin \\ [CAS No. 309-00-2]
}

Naomi L. Hudson and G. Scott Dotson 


\section{This document is in the public domain and may be freely copied or reprinted.}

\section{Disclaimer}

Mention of any company or product does not constitute endorsement by the National Institute for Occupational Safety and Health (NIOSH). In addition, citations to websites external to NIOSH do not constitute NIOSH endorsement of the sponsoring organizations or their programs or products. Furthermore, NIOSH is not responsible for the content of these websites. All Web addresses referenced in this document were accessible as of the publication date.

\section{Ordering Information}

To receive this document or information about other occupational safety and health topics, contact NIOSH:

Telephone: 1-800-CDC-INFO (1-800-232-4636)

TTY: $1-888-232-6348$

CDC-INFO: www.cdc.gov/info

or visit the NIOSH website at www.cdc.gov/niosh.

For a monthly update on news at NIOSH, subscribe to NIOSH eNews by visiting www.cdc.gov/niosh/eNews.

\section{Suggested Citation}

NIOSH [2015]. NIOSH skin notation profile: Aldrin. By Hudson NL, Dotson GS. Cincinnati, OH: U.S. Department of Health and Human Services, Centers for Disease Control and Prevention, National Institute for Occupational Safety and Health, DHHS (NIOSH) Publication No. 2015-191

DHHS (NIOSH) Publication No. 2015-191

July 2015

SAFER • HEALTHIER • PEOPLETM 


\title{
Foreword
}

As the largest organ of the body, the skin performs multiple critical functions, such as serving as the primary barrier to the external environment. For this reason, the skin is often exposed to potentially hazardous agents, including chemicals, which may contribute to the onset of a spectrum of adverse health effects ranging from localized damage (e.g., irritant contact dermatitis and corrosion) to induction of immune-mediated responses (e.g., allergic contact dermatitis and pulmonary responses), or systemic toxicity (e.g., neurotoxicity and hepatoxicity). Understanding the hazards related to skin contact with chemicals is a critical component of modern occupational safety and health programs.

In 2009, the National Institute for Occupational Safety and Health (NIOSH) published Current Intelligence Bulletin (CIB) 61: A Strategy for Assigning New NIOSH Skin Notations [NIOSH 2009-147]. This document provides the scientific rationale and framework for the assignment of multiple hazard-specific skin notations (SK) that clearly distinguish between the systemic effects, direct (localized) effects, and immune-mediated responses caused by skin contact with chemicals. The key step within assignment of the hazard-specific SK is the determination of the hazard potential of the substance, or its potential for causing adverse health effects as a result of skin exposure. This determination entails a health hazard identification process that involves use of the following:

- Scientific data on the physicochemical properties of a chemical

- Data on human exposures and health effects

- Empirical data from in vivo and in vitro laboratory testing

- Computational techniques, including predictive algorithms and mathematical models that describe a selected process (e.g., skin permeation) by means of analytical or numerical methods.

This Skin Notation Profle provides the SK assignments and supportive data for aldrin. In particular, this document evaluates and summarizes the literature describing the hazard potential of the substance and its assessment according to the scientific rationale and framework outlined in CIB 61. In meeting this objective, this Skin Notation Profile intends to inform the audience-mostly occupational health practitioners, researchers, policy- and decision-makers, employers, and workers in potentially hazardous workplaces-so that improved risk-management practices may be developed to better protect workers from the risks of skin contact with the chemicals of interest.

\author{
John Howard, M.D. \\ Director, National Institute for \\ Occupational Safety and Health \\ Centers for Disease Control and Prevention
}


This page intentionally left blank. 


\section{Contents}

Foreword $\ldots \ldots \ldots \ldots \ldots \ldots \ldots \ldots \ldots \ldots \ldots \ldots \ldots \ldots \ldots \ldots \ldots \ldots$ iii

Abbreviations ......................... vi

Glossary .................................. viii

Acknowledgments ....................... ix

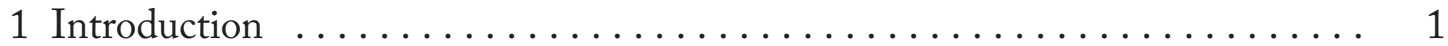

1.1 General Substance Information $\ldots \ldots \ldots \ldots \ldots \ldots \ldots \ldots \ldots$

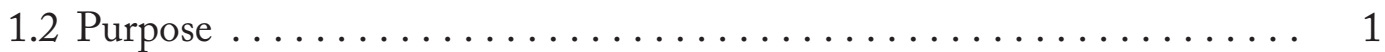

1.3 Overview of SK Assignment . . . . . . . . . . . . . . 1

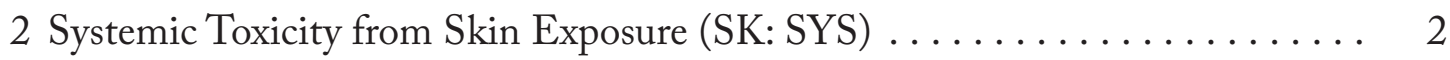

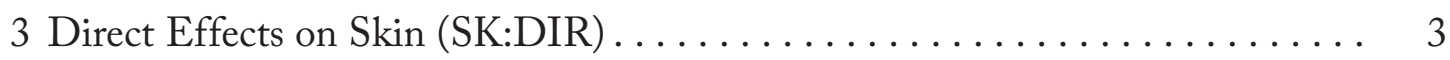

4 Immune-mediated Responses $(\mathrm{SK}: \mathrm{SEN}) \ldots \ldots \ldots \ldots \ldots \ldots \ldots \ldots \ldots$

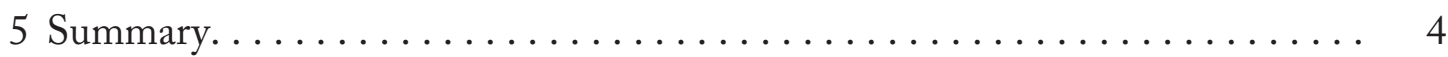

Appendix: Calculation of the SI Ratio $\ldots \ldots \ldots \ldots \ldots \ldots \ldots \ldots \ldots$

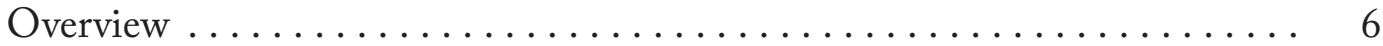

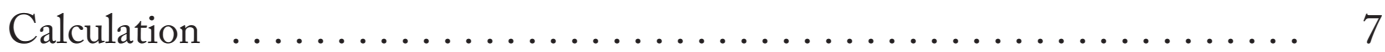

Appendix References ....................... 7

Skin Notation Profiles | Aldrin $\quad$ v 


\title{
Abbreviations
}

\author{
ACGIH American Conference of Governmental Industrial Hygienists \\ ATSDR Agency for Toxic Substances and Disease Registry \\ CIB Current Intelligence Bulletin \\ $\mathrm{cm}^{2} \quad$ square centimeter(s) \\ $\mathrm{cm} / \mathrm{hr} \quad$ centimeter(s) per hour \\ $\mathrm{cm} / \mathrm{s} \quad$ centimeter(s) per second \\ DEREK Deductive Estimation of Risk from Existing Knowledge \\ DIR skin notation indicating the potential for direct effects to the skin following \\ contact with a chemical \\ EC European Commission \\ g $\quad \operatorname{gram}(\mathrm{s})$ \\ g/L gram(s)/liter \\ GHS Globally Harmonized System for Classification and Labelling of Chemicals \\ GPMT guinea pig maximization test \\ hr hour(s) \\ IARC International Agency for Research on Cancer \\ IPCS International Program for Chemical Safety \\ (IRR) subnotation of SK: DIR indicating the potential for a chemical to be a skin ir- \\ ritant following exposure to the skin \\ $k_{a q} \quad$ coefficient in the watery epidermal layer \\ $k_{p} \quad$ skin permeation coefficient \\ $k_{\text {pol }} \quad$ coefficient in the protein fraction of the stratum corneum \\ $k_{p s c} \quad$ permeation coefficient in the lipid fraction of the stratum corneum \\ $\mathrm{LD}_{50} \quad$ dose resulting in $50 \%$ mortality in the exposed population \\ $\mathrm{LD}_{\mathrm{Lo}} \quad$ dermal lethal dose \\ LLNA local lymph node assay \\ LOAEL lowest-observed-adverse-effect level \\ $\log K_{\text {OW }} \quad$ base-10 logarithm of a substance's octanol-water partition \\ Molarity \\ $\mathrm{m}^{3} \quad$ cubic meter(s) \\ $\mathrm{mg} \quad$ milligram(s) \\ $\mathrm{mg} / \mathrm{cm}^{2} / \mathrm{hr}$ milligram(s) per square centimeter per hour \\ $\mathrm{mg} / \mathrm{kg} \quad$ milligram(s) per kilogram body weight \\ $\mathrm{mg} / \mathrm{m}^{3} \quad$ milligram(s) per cubic meter \\ $\mathrm{mL} \quad$ milliliter(s) \\ $\mathrm{mL} / \mathrm{kg} \quad$ milliliter(s) per kilogram body weight \\ MW molecular weight \\ NIOSH National Institute for Occupational Safety and Health \\ NOAEL no-observed-adverse-effect level
}


NTP National Toxicology Program

OEL occupational exposure limit

OSHA Occupational Safety and Health Administration

ppm parts per million

REL recommended exposure limit

$\mathrm{RF} \quad$ retention factor

SEN skin notation indicating the potential for immune-mediated reactions following exposure of the skin

SI ratio ratio of skin dose to inhalation dose

SK skin notation

$S_{W} \quad$ solubility in water

SYS skin notation indicating the potential for systemic toxicity following exposure of the skin

US EPA United States Environmental Protection Agency

$\mu \mathrm{g} \quad \operatorname{microgram}(\mathrm{s})$

$\mu \mathrm{g} / \mathrm{cm}^{2} \quad$ microgram(s) per square centimeter

$\mu \mathrm{g} / \mathrm{cm}^{2} / \mathrm{hr}$ microgram(s) per square centimeter per hour

$\mu \mathrm{L} \quad$ microliter(s)

$\mu$ mol micromole(s) 


\section{Glossary}

Absorption-The transport of a chemical from the outer surface of the skin into both the skin and systemic circulation (including penetration, permeation, and resorption).

Acute exposure-Contact with a chemical that occurs once or for only a short period of time.

Cancer-Any one of a group of diseases that occurs when cells in the body become abnormal and grow or multiply out of control.

Contaminant-A chemical that is (1) unintentionally present within a neat substance or mixture at a concentration less than $1.0 \%$ or (2) recognized as a potential carcinogen and present within a neat substance or mixture at a concentration less than $0.1 \%$.

Cutaneous (or percutaneous)-Referring to the skin (or through the skin).

Dermal-Referring to the skin.

Dermal contact-Contact with (touching) the skin.

Direct effects-Localized, non-immune-mediated adverse health effects on the skin, including corrosion, primary irritation, changes in skin pigmentation, and reduction/ disruption of the skin barrier integrity, occurring at or near the point of contact with chemicals.

Immune-mediated responses-Responses mediated by the immune system, including allergic responses.

Sensitization-A specific immune-mediated response that develops following exposure to a chemical, which, upon re-exposure, can lead to allergic contact dermatitis (ACD) or other immune-mediated diseases such as asthma, depending on the site and route of re-exposure.

Substance-A chemical.

Systemic effects-Systemic toxicity associated with skin absorption of chemicals after exposure of the skin. 


\section{Acknowledgments}

This document was developed by the NIOSH Education and Information Division (Paul Schulte, Ph.D., Director). G. Scott Dotson, Ph.D., was the project officer for this document, assisted in great part by Naomi Hudson, Dr.P.H., MPH; Vic Johnson, Ph.D.; and John Snawder, Ph.D. The basis for this document was a report (Toxicology Excellence for Risk Assessment [TERA]) contracted by NIOSH and prepared by Bernard Gadagbui, Ph.D. and Andrew Maier, Ph.D.

For their contribution to the technical content and review of this document, special acknowledgment is given to the following NIOSH personnel:

\section{Denver Field Office}

Eric Esswein, M.Sc.

\section{Division of Applied Research and Technology}

Clayton B'Hymer, Ph.D.

Mark Toraason, Ph.D.

\section{Division of Respiratory Disease Studies}

Gregory A. Day, Ph.D.

Aleksander Stefaniak, Ph.D.

\section{Division of Surveillance, Hazard Evaluations, and Field Studies}

Matt Dahm, M.Sc.

Todd Niemeier, M.Sc.

Aaron Sussell, Ph.D.

Loren Tapp, M.D.

\section{Education and Information Division}

Devin Baker, M.Ed.

Charles L. Geraci, Ph.D.

Thomas J. Lentz, Ph.D.

Richard Niemeier, Ph.D.

Sudha Pandalai, M.D., Ph.D.

\section{Health Effects Laboratory Division}

Stacey Anderson, Ph.D.

H. Fredrick Frasch, Ph.D.

Michael Luster, Ph.D.

Anna Shvedova, Ph.D.

Paul Siegel, Ph.D.

Berran Yucesoy, Ph.D.

\section{National Personal Protection Technology Laboratory}

Heinz Ahlers, M.Sc.

Angie Shephard 
For their contribution to the technical content and review of this document, special acknowledgment is given to the following CDC personnel:

\section{Office of Surveillance, Epidemiology and Laboratory Services/Epidemiology and Analysis Program Office}

Barbara Landreth, M.A.

In addition, special appreciation is expressed to the following individuals for serving as independent, external reviewers and providing comments that contributed to the development or improvement of this document:

Phil Bigelow, B.Sc., M.H.Sc., Ph.D., University of Waterloo, School of Public Health and Health Systems, Waterloo, ON, Canada

John Herbold, DVM, PhD, MPH., San Antonio, TX

G. Frank Gerberick, Ph.D., The Procter and Gamble Company, Cincinnati, OH

Dori Germolec, Ph.D., National Toxicology Program, National Institute for Environmental Health Sciences, Research Triangle, NC

Ben Hayes, M.D., Ph.D., Division of Dermatology, Vanderbilt School of Medicine, Nashville, TN

Jennifer Sahmel, M.Sc., CIH, ChemRisk, Boulder, CO

James Taylor, M.D., Industrial Dermatology, The Cleveland Clinic, Cleveland, OH 


\section{Introduction}

\subsection{General Substance Information}

Chemical: Aldrin

CAS No: $309-00-2$

Molecular weight $(M W): 364.9$

Molecular formula: $\mathrm{C}_{12} \mathrm{H}_{8} \mathrm{C}_{16}$

Structural formula:

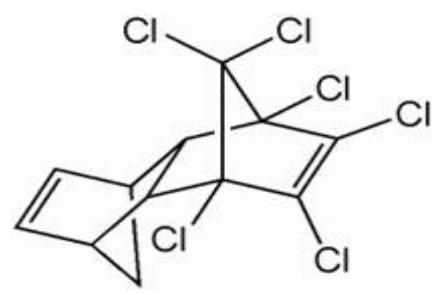

\section{Synonyms:}

1,2,3,4,10,10-Hexachloro-1,4,4a,5,8,8a-

hexahydro-endo-1,4-exo-5,8-dimeth-

anonaphthalene; HHDN; Octalene

Uses:

Aldrin is an organochlorine pesticide; approximately 11 million pounds (4.8 million kilograms) of aldrin were used in 1970 [ATSDR 2002]. Due to concerns about carcinogenicity, bioaccumulation, hazards to wildlife and the chronic effects of aldrin, all products containing aldrin were cancelled [US EPA 1990]. Currently there is no use for aldrin in the US.

\subsection{Purpose}

This skin notation profile presents (1) a brief summary of epidemiological and toxicological data associated with skin contact with aldrin and (2) the rationale behind the hazard-specific skin notation (SK) assignment for aldrin. The SK assignment is based on the scientific rationale and logic outlined in the Current Intelligence Bulletin (CIB) 61: A Strategy for Assigning New NIOSH Skin Notations [NIOSH 2009]. The summarized information and health hazard assessment are limited to an evaluation of the potential health effects of dermal exposure to aldrin. A literature search was conducted through September 2014 to identify information on aldrin, including but not limited to data relating to its toxicokinetics, acute toxicity, repeated-dose systemic toxicity, carcinogenicity, biological system/ function-specific effects (including reproductive and developmental effects and immunotoxicity), irritation, and sensitization. Information was considered from studies of humans, animals, or appropriate modeling systems that are relevant to assessing the effects of dermal exposure to aldrin.

\subsection{Overview of SK Assignment}

Aldrin is potentially capable of causing numerous adverse health effects following skin contact. A critical review of available data has resulted in the following SK assignment for aldrin: SK: SYS (FATAL). Table 1 provides an overview of the critical effects and data used to develop the SK assignment for aldrin.

Table 1. Summary of the SK assignment for adrin

\begin{tabular}{ccc}
\hline Skin notation & Critical effect & Available data \\
\hline SK: SYS (FATAL) & $\begin{array}{c}\text { Central nervous system } \\
\text { effects; acute toxicity }\end{array}$ & $\begin{array}{c}\text { Limited human and sufficient } \\
\text { animal data }\end{array}$ \\
\hline
\end{tabular}




\section{Systemic Toxicity from Skin Exposure (SK: SYS)}

A limited number of toxicokinetic studies were identified in humans and animals following dermal exposure to aldrin. In one study, Feldmann and Maibach [1974] reported dermal absorption of $7.8 \%$ of the applied aldrin dose (based on total urinary excretion over a 5-day period) in six human volunteers that received a single dermal application of 0.004 milligrams per square centimeter $(\mathrm{mg} /$ $\mathrm{cm}^{2}$ ) of aldrin to the unprotected forearm for 24 hours. The potential of aldrin to pose a skin absorption hazard was evaluated, with use of a predictive algorithm for estimating and evaluating the health hazards of dermal exposure to substances [NIOSH 2009]. The evaluation method compares an estimated dose accumulated in the body from skin absorption and an estimated dose from respiratory absorption associated with a reference occupational exposure limit. On the basis of this algorithm, a ratio of the skin dose to the inhalation dose (SI ratio) of 0.0019 was calculated for aldrin. An SI ratio of $\geq 0.1$ indicates that a chemical is capable of producing systemic toxicity from skin exposure [NIOSH 2009]; therefore, aldrin is not considered to be absorbed through the skin following dermal exposure. Additional information on the SI ratio and the variables used in its calculation are included in the appendix.

While no dermal lethal concentration $\left(\mathrm{LD}_{\mathrm{Lo}}\right)$ for humans has been identified, the reported dermal $\mathrm{LD}_{50}$ values (the dose resulting in 50\% mortality in the exposed animals) have ranged from 98 to 274 milligrams per kilogram of bodyweight $(\mathrm{mg} / \mathrm{kg})$ [Gaines 1960 ] in rats, and 15 to $150 \mathrm{mg} / \mathrm{kg}$ in rabbits [Lehman 1952; Johnston and Eden 1953], depending on the vehicle used. Symptoms following exposure to Aldrin in rabbits included loss of appetite, nervousness, and convulsions [Lehman 1952; Johnston and Eden 1953]. Because the majority of reported acute dermal $\mathrm{LD}_{50}$ values for all species are lower than the critical dermal $\mathrm{LD}_{50}$ value of $200 \mathrm{mg} / \mathrm{kg}$ that identifies chemical substances with the potential for acute dermal toxicity [NIOSH 2009], aldrin is considered acutely fatal following dermal exposure.

Although many occupational studies of workers employed in either the manufacture or application of aldrin and dieldrin - a metabolite of aldrin-reported central nervous system effects as the principal toxic effect [Kazantzis et al. 1964; Hoogendam et al. 1965; de Jong 1991], including convuslions and ataxia [Kazantzis et al. 1964]. Exposures involved both inhalation and dermal exposure; however, the contribution from dermal exposure to these effects was not quantified.

Human epidemiological studies [de Jong et al. 1991; Amoateng-Adjepong et al. 1995; de Jong et al. 1997] conducted in two aldrin and dieldrin manufacturing plants determined an observed increase in hepatobiliary cancer incidence was not due to occupational exposure, and that an observed significant increase in mortality from rectal cancer did not demonstrate a dose-response relationship. As is the case with many occupational studies, the dermal contribution to the total exposure was not quantified.

No repeat-dose, subchronic, or chronic dermal toxicity studies in animals were available for evaluation. No standard toxicity or specialty studies that evaluated biological system/ function specific effects (including reproductive and developmental effects and immunotoxicity) following dermal exposure to aldrin were identified.

No studies were identified that evaluated the potential of aldrin to be carcinogenic in animals following dermal exposure. Table 2 summarizes carcinogenic designations of multiple governmental and nongovernmental organizations for aldrin.

Although dermal absorption data of aldrin in humans are limited and the predictive mathematical model (see Appendix) did not indicate that the chemical can be absorbed through the skin, acute toxicity studies report 
Table 2. Summary of the carcinogenic designations* for aldrin by numerous governmental and nongovernmental organizations

\begin{tabular}{ll}
\hline \multicolumn{1}{c}{ Organization } & \multicolumn{1}{c}{ Carcinogenic designation } \\
\hline NIOSH [2005] & Carcinogen \\
NTP [2014] & No designation \\
US EPA [2014] & B2: probable human carcinogen \\
European Parliament [2008] & GHS Carcinogenicity Category 2: suspected of \\
& causing cancer \\
IARC [2012] & Group 3: not classifiable as to carcinogenicity \\
& to humans \\
EC [2014] ${ }^{\dagger}$ & R40: limited evidence of carcinogenic effect \\
ACGIH [2007] & A3: confirmed animal carcinogen with unknown \\
& relevance to humans \\
\hline
\end{tabular}

ACGIH = American Conference of Governmental Industrial Hygienists; EC = European Commission, Joint Research, Institute for Health and Consumer Protection; GHS = Globally Harmonized System for Classification and Labelling of Chemicals; IARC = International Agency for Research on Cancer; NIOSH = National Institute for Occupational Safety and Health; NTP = National Toxicology Program; USEPA = United States Environmental Protection Agency.

*The listed cancer designations were based on data from nondermal (such as oral or inhalation) exposure rather than dermal exposure.

${ }^{\dagger}$ Date accessed.

$\mathrm{LD}_{50}$ values generally less than $200 \mathrm{mg} / \mathrm{kg}$ [Lehman 1952; Johnston and Eden 1953; Gaines 1960].* Potential central nervous system effects from exposure to aldrin were reported in the acute toxicity studies and human epidemiological studies [de Jong et al. 1991; Amoateng-Adjepong et al. 1995; de Jong et al. 1997]. However, the epidemiological studies likely involved both inhalation and dermal routes of exposure. Therefore, on the basis of the data for this assessment, aldrin is assigned the SK: SYS (FATAL) notation.

\section{Direct Effects on Skin (SK:DIR)}

No human or animal in vivo studies for corrosivity of aldrin or in vitro tests for corrosivity using human or animal skin models or in vitro tests of skin integrity using cadaver skin were identified. Occupational studies involving workers employed for four or more years in the manufacture of aldrin reported minor erythema [Jager 1970]. The structure-activity

*References in bold text indicate studies that serve as the basis of the SK assignments. relationship model, Deductive Estimation of Risk from Existing Knowledge (DEREK) for Windows, predicted aldrin to be negative for skin irritation. The limited data describing the direct skin effects of dermal exposure to aldrin precludes adequate evaluation of the corrosivity or irritancy potential of the substance. Therefore, on the basis of the data for this assessment, aldrin is not assigned the SK: DIR (IRR) notation.

\section{Immune-mediated Responses (SK: SEN)}

A limited number of studies were identified that evaluated the potential of aldrin to cause skin sensitization in both humans and animals. Jager [1970] found no cases of skin sensitization over a period of 20 years in a group of over 1000 workers involved in the manufacture and formulation of aldrin and dieldrin. The structure activity relationship model, DEREK for Windows, predicted aldrin to be positive for skin sensitization. However, the positive results of the predictive model are insufficient to demonstrate the skin sensitization potential 
of aldrin. The lack of data precludes an adequate evaluation of the sensitization potential of the chemical. Therefore, on the basis of the data for this assessment, aldrin is not assigned the SK: SEN notation.

\section{Summary}

Although dermal absorption data of aldrin in humans are limited and the predictive mathematical model (see Appendix) did not indicate that the chemical can be absorbed through the skin, acute toxicity studies report $\mathrm{LD}_{50}$ values generally less than $200 \mathrm{mg} /$ $\mathrm{kg}$ [Lehman 1952; Johnston and Eden 1953; Gaines 1960]. Potential central nervous system effects from exposure to aldrin were reported in the acute toxicity studies and human epidemiological studies [de Jong et al. 1991; Amoateng-Adjepong et al. 1995; de Jong et al. 1997]. However, the epidemiological studies likely involved both inhalation and dermal routes of exposure. Insufficient human data and conflicting animal data preclude adequate assessment of skin irritation or sensitization potential of aldrin. Therefore, on the basis of these assessments, aldrin is assigned a composite skin notation of SK: SYS (FATAL).
Table 3 summarizes the skin hazard designations for aldrin previously issued by NIOSH and other organizations. The equivalent dermal designations for aldrin, according to the Global Harmonization System (GHS) of Classification and Labelling of Chemicals, are Acute Toxicity Category 3 (Hazard statement: Toxic in contact with the skin) [European Parliament 2008].

\section{References}

ACGIH (American Conference of Governmental Industrial Hygienists) [2007]. Aldrin. In: 2014 TLVs and BEIs, Based on the documentation of the threshold limit values for chemical substances and physical agents and biological exposure indices. Cincinnati, $\mathrm{OH}$ : American Conference of Governmental Industrial Hygienists.

Amoateng-Adjepong Y, Sathiakumar N, Delzell E, Cole P [1995]. Mortality among workers at a pesticide manufacturing plant. J Occup Environ Med 37(4):471-478.

ATSDR [2002]. Toxicological profile for aldrin/ dieldrin. Atlanta: U.S. Department of Health and Human Services, Public Health Service, Agency for Toxic Substances and Disease Registry, http://www.atsdr.cdc.gov/ToxProfiles/ tp.asp?id=317\&tid=56. Accessed: $02-10-15$.

de Jong G [1991]. Long-term health effects of aldrin and dieldrin: A study of exposure, health

\section{Table 3. Summary of previous skin hazard designations for aldrin}

\begin{tabular}{ll}
\hline Organization & Skin hazard designation \\
\hline NIOSH [2005] & [skin]: potential for dermal absorption \\
OSHA [2015]* & [skin]: potential for dermal absorption \\
ACGIH [2007] & [skin]: based on absorption and deposition of aldrin in sub- \\
& cutaneous fat and toxic effects in the liver and kidneys of \\
& animals following topical application \\
EC [2014] & R24: toxic in contact with skin \\
& R48: toxic: danger of serious damage to health by pro- \\
& longed exposure in contact with skin. \\
\hline
\end{tabular}

ACGIH = American Conference of Governmental Industrial Hygienists; EC = European Commission, Joint Research, Institute for Health and Consumer Protection; NIOSH = National Institute for Occupational Safety and Health; OSHA = Occupational Safety and Health Administration.

*Date accessed. 
effects and mortality of workers engaged in the manufacture and formulation of the insecticides aldrin and dieldrin. Amsterdam, Netherlands: Elsevier Science Publishers B.V.

de Jong G, Swaen GMH, Slangen JJM [1997]. Mortality of workers exposed to dieldrin and aldrin: A retrospective cohort study. Occup Environ Med 54:702-707.

EC (European Commission) [ND]. Aldrin. In: EINICS (European Inventory of Exisiting Commerical Chemical Substances), http://esis. jrc.ec.europa.eu/. Accessed: 8-28-14.

European Parliament, Council of the European Union [2008]. Regulation (EC) No 1272/2008 of the European Parliament and of the Council of 16 December 2008 on classification, labeling and packaging of substances and mixtures, amending and repealing Directives 67/548/

EEC and 1999/45/EC, and amending Regulation (EC) No 1907/2006. OJEU, Off J Eur Union L353:1-1355, http://eurex.europa.eu/ LexUriServ/LexUriServ.do?uri=OJ:L:2008:35 3:0001:1355:EN:PDF. Accessed: 02-10-15.

Feldman RJ, Maibach HI [1974]. Percutaneous penetration of some pesticides and herbicides in man. Toxicol Appl Pharmacol 28:126-132.

Gaines TB [1960]. The acute toxicity of pesticides to rats. Toxico Appl Pharmacol. 2:88-99.

Hoogendam I, Versteeg JPJ, DeVlieger M [1965]. Nine years toxicity control in insecticide plants. Arch Environ Health 10:441-448.

IARC (International Agency for Research on Cancer) [2012]. Agents reviewed by the IARC monographs. In: IARC monographs on the evaluation of carcinogenic risks to humans, http://monographs.iarc.fr/ENG/Monographs/ PDFs/index.php. Accessed: 02-10-15.

Jager KW [1970]. Aldrin, dieldrin, endrin and telodrin: An epidemiological and toxicological study of long-term occupational exposure. New York: Elsevier.

Johnston BL, Eden WG [1953]. The Toxicity of Aldrin, Dieldrin, and Toxaphene to Rabbits by Skin Absorption. Journal of Economic Entomology 46(4):702-703.

Kazantzis G, McLaughlin AIG, Prior PF [1964]. Poisoning in industrial workers by the insecticide aldrin. Br J In Med 21:46-51.
Lehman AJ [1952]. Chemicals in foods: a report to the Association of Food and Drug Officials on current developments. Part II. Pesticides. Section II. Dermal toxicity. Q Bull Assoc Food Drug Off. (USA), 16:3-9.

NIOSH [2005]. Aldrin. In: NIOSH pocket guide to chemical hazards. Cincinnati, OH: U.S. Department of Health and Human Services, Centers for Disease Control and Prevention, National Institute for Occupational Safety and Health, DHHS (NIOSH) Publication No. 2005-149, http://www.cdc.gov/niosh/npg/ npgd0211.html. Accessed 02-10-15.

NIOSH [2009]. Current intelligence bulletin 61: a strategy for assigning new NIOSH skin notations. Cincinnati, OH: U.S. Department of Health and Human Services, Centers for Disease Control and Prevention, National Institute for Occupational Safety and Health, DHHS (NIOSH) Publication No. 2009-147, http://www.cdc.gov/niosh/docs/2009-147/ pdfs/2009-147.pdf. Accessed: 02-10-15.

NTP [2014]. Report on carcinogens. Thirteenth Edition; U.S. Department of Health and $\mathrm{Hu}-$ man Services, Public Health Service. National Toxicology Program, http://ntp.niehs.nih. gov/pubhealth/roc/roc13/index.htm1. Accessed: 02-10-15.

OSHA [ND]. Aldrin. In: OSHA/EPA occupational chemical database, http://www.osha.gov/ chemicaldata/chemResult.html? recNo=349. Accessed: 02-10-15.

US EPA [1990]. Suspended, cancelled, and restricted pesticides. Pesticides and Toxic Substances EN-342. Washington, DC: United States Environmental Protection Agency, http://nepis.epa.gov/EPA/html/ DLwait.htm?url=/Exe/ZyPDF.cgi/20011 E0G.PDF? Dockey=20011E0G.PDF. Accessed: 02-10-15.

US EPA [2014]. Aldrin. Integrated Risk Information System. Washington, DC: United States Environmental Protection Agency, http://www.epa.gov/iris/subst/0130.htm. Accessed: 02-10-15. 


\section{Appendix: Calculation of the SI Ratio}

This appendix presents an overview of the SI ratio and a summary of the calculation of the SI ratio for aldrin. Although the SI ratio is considered in the determination of a substance's hazard potential following skin contact, it is intended only to serve as supportive data during the assignment of the NIOSH SK. An in-depth discussion on the rationale and calculation of the SI ratio can be found in Appendix B of the Current Intelligence Bulletin (CIB) 61: A Strategy for Assigning New NIOSH Skin Notations [NIOSH 2009].

\section{Overview}

The SI ratio is a predictive algorithm for estimating and evaluating the health hazards of skin exposure to substances. The algorithm is designed to evaluate the potential for a substance to penetrate the skin and induce systemic toxicity [NIOSH 2009]. The goals for incorporating this algorithm into the proposed strategy for assigning SYS notation are as follows:

1. Provide an alternative method to evaluate substances for which no clinical reports or animal toxicity studies exist or for which empirical data are insufficient to determine systemic effects.

2. Use the algorithm evaluation results to determine whether a substance poses a skin absorption hazard and should be labeled with the SYS notation.

The algorithm evaluation includes three steps:

1. Determining a skin permeation coefficient $\left(k_{p}\right)$ for the substance of interest.

2. Estimating substance uptake by the skin and respiratory absorption routes.

3. Evaluating whether the substance poses a skin exposure hazard.

The algorithm is flexible in the data requirement and can operate entirely on the basis of the physicochemical properties of a substance and the relevant exposure parameters. Thus, the algorithm is independent of the need for biologic data. Alternatively, it can function with both the physicochemical properties and the experimentally determined permeation coefficient when such data are available and appropriate for use.

The first step in the evaluation is to determine the $k_{p}$ for the substance to describe the transdermal penetration rate of the substance [NIOSH 2009]. The $k_{p}$, which represents the overall diffusion of the substance through the stratum corneum and into the blood capillaries of the dermis, is estimated from the compound's molecular weight $(M W)$ and base-10 logarithm of its octanol-water partition coefficient $\left(\log K_{O W}\right)$. In this example, $k_{p}$ is determined for a substance with use of Equation 1. A self-consistent set of units must be used, such as centimeters per hour $(\mathrm{cm} / \mathrm{hr})$, outlined in Table A1. Other model-based estimates of $k_{p}$ may also be used [NIOSH 2009].

\section{Equation 1: Calculation of Skin Permeation Coefficient $\left(\boldsymbol{k}_{\boldsymbol{p}}\right)$

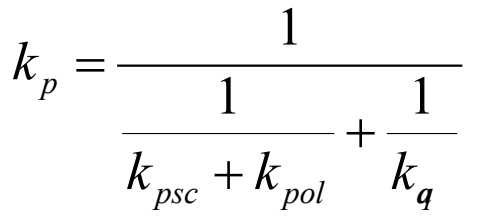

where $k_{p s c}$ is the permeation coefficient in the lipid fraction of the stratum corneum, $k_{p o l}$ is the coefficient in the protein fraction of the stratum corneum, and $k_{a q}$ is the coefficient in the watery epidermal layer. These components are individually estimated by

$$
\begin{aligned}
\log K_{p s c}= & -1.326+0.6097 \times \log K_{o w}- \\
& 0.1786 \times M W^{0.5} \\
K_{p o l}= & 0.0001519 \times M W^{-0.5} \\
K_{a q}= & 2.5 \times M W^{-0.5}
\end{aligned}
$$

The second step is to calculate the biologic mass uptake of the substance from skin absorption (skin dose) and inhalation (inhalation 
dose) during the same period of exposure. The skin dose is calculated as a mathematical product of the $k_{p}$, the water solubility $\left(S_{w}\right)$ of the substance, the exposed skin surface area, and the duration of exposure. Its units are milligrams (mg). Assume that the skin exposure continues for 8 hours to unprotected skin on the palms of both hands (a surface area of 360 square centimeters $\left.\left[\mathrm{cm}^{2}\right]\right)$.

\section{Equation 2: Determination of Skin Dose}

$$
\begin{aligned}
\text { Skin dose }= & k_{p} \times S_{w} \times \text { Exposed skin surface } \\
& \text { area } \times \text { Exposure time } \\
= & k_{p}(\mathrm{~cm} / \text { hour }) \times S_{w}\left(\mathrm{mg} / \mathrm{cm}^{3}\right) \times \\
& 360 \mathrm{~cm}^{2} \times 8 \text { hours }
\end{aligned}
$$

The inhalation dose (in $\mathrm{mg}$ ) is derived on the basis of the occupational exposure limit (OEL) of the substance-if the OEL is developed to prevent the occurrence of systemic effects rather than sensory/irritant effects or direct effects on the respiratory tract. Assume a continuous exposure of 8 hours, an inhalation volume of 10 cubic meters $\left(\mathrm{m}^{3}\right)$ inhaled air in 8 hours, and a factor of $75 \%$ for retention of the airborne substance in the lungs during respiration (retention factor, or RF).

\section{Equation 3: Determination of Inhalation Dose}

$$
\begin{aligned}
\text { Inhalation dose }= & \text { OEL } \times \text { Inhalation } \\
& \text { volume } \times \mathrm{RF} \\
= & \text { OEL }\left(\mathrm{mg} / \mathrm{m}^{3}\right) \times 10 \mathrm{~m}^{3} \times 0.75
\end{aligned}
$$

The final step is to compare the calculated skin and inhalation doses and to present the result as a ratio of skin dose to inhalation dose (the SI ratio). This ratio quantitatively indicates (1) the significance of dermal absorption as a route of occupational exposure to the substance and (2) the contribution of dermal uptake to systemic toxicity. If a substance has an SI ratio greater than or equal to 0.1 , it is considered a skin absorption hazard.

\section{Calculation}

Table A1 summarizes the data applied in the previously described equations to determine the SI ratio for aldrin. The calculated SI ratio was 0.0019 . On the basis of these results, aldrin is not predicted to represent a skin absorption hazard.

\section{Appendix References}

NIOSH [2005]. NIOSH pocket guide to chemical hazards. Cincinnati, OH: U.S. Department of Health and Human Services, Centers for Disease Control and Prevention, National Institute for Occupational Safety and Health, DHHS (NIOSH) Publication No. 2005-149, http:// www.cdc.gov/niosh/npg/. Accessed: 02-10-15.

NIOSH [2009]. Current intelligence bulletin 61: a strategy for assigning new NIOSH skin notations. Cincinnati, OH: U.S. Department of Health and Human Services, Centers for Disease Control and Prevention, National Institute for Occupational Safety and Health, DHHS (NIOSH) Publication No. 2009-147, http:// www.cdc.gov/niosh/docs/2009-147/pdfs/2009147.pdf. Accessed: 02-10-15.

SRC [ND]. Interactive PhysProp database demo, http://www.srcinc.com/what-we-do/databaseforms.aspx?id=386. Accessed: 02-10-15. 
Table A1. Summary of data used to calculate the SI ratio for aldrin

\begin{tabular}{|c|c|c|}
\hline Variables used in calculation & Units & Value \\
\hline \multicolumn{3}{|l|}{ Skin permeation coefficient } \\
\hline Permeation coefficient of stratum corneum lipid path $\left(k_{p s c}\right)$ & $\mathrm{cm} / \mathrm{hr}$ & 0.168 \\
\hline $\begin{array}{l}\text { Permeation coefficient of the protein fraction of the stra- } \\
\text { tum corneum }\left(k_{p o l}\right)\end{array}$ & $\mathrm{cm} / \mathrm{hr}$ & $7.952 \times 10^{-6}$ \\
\hline Permeation coefficient of the watery epidermal layer $\left(k_{a q}\right)$ & $\mathrm{cm} / \mathrm{hr}$ & 0.1309 \\
\hline Molecular weight $(M W)^{*}$ & $\mathrm{amu}$ & 364.9 \\
\hline $\begin{array}{l}\text { Base-10 logarithm of its octanol-water partition coeffi- } \\
\text { cient }\left(\log K_{o w}\right)^{*}\end{array}$ & None & 6.5 \\
\hline Calculated skin permeation coefficient $\left(k_{p}\right)$ & $\mathrm{cm} / \mathrm{hr}$ & 0.0736 \\
\hline \multicolumn{3}{|l|}{ Skin dose } \\
\hline Water solubility $\left(S_{w}\right)^{*}$ & $\mathrm{mg} / \mathrm{cm}^{3}$ & $1.7 \times 10^{-5}$ \\
\hline Calculated skin permeation coefficient $\left(k_{p}\right)$ & $\mathrm{cm} / \mathrm{hr}$ & 0.0736 \\
\hline Estimated skin surface area (palms of hand) & $\mathrm{cm}^{2}$ & 360 \\
\hline Exposure time & $\mathrm{hr}$ & 8 \\
\hline Calculated skin dose & $\mathrm{mg}$ & 0.0036 \\
\hline \multicolumn{3}{|l|}{ Inhalation Dose } \\
\hline Occupational exposure limit $(\mathrm{OEL})^{\dagger}$ & $\mathrm{mg} / \mathrm{m}^{3}$ & 0.25 \\
\hline Inhalation volume & $\mathrm{m}^{3}$ & 10 \\
\hline Retention factor (RF) & None & 0.75 \\
\hline Inhalation dose & $\mathrm{mg}$ & 1.875 \\
\hline Skin dose-to-inhalation dose (SI) ratio & None & 0.0019 \\
\hline
\end{tabular}

*Variables identified from SRC [ND].

The OEL used in calculation of the SI ratio for aldrin was the NIOSH recommended exposure limit (REL) [NIOSH 2005]. 
This page intentionally left blank. 
This page intentionally left blank. 
This page intentionally left blank. 


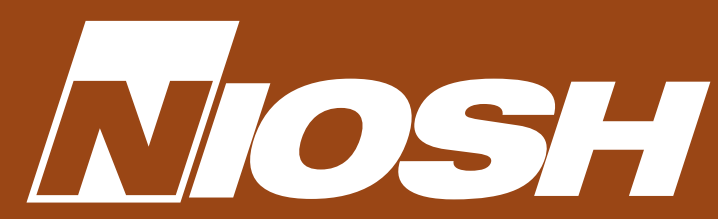

Delivering on the Nation's promise: safety and health at work for all people through research and prevention

To receive NIOSH documents or more information about occupational safety and health topics, contact $\mathrm{NIOSH}$ at

1-800-CDC-INFO (1-800-232-4636)

TTY: 1-888-232-6348

CDC-INFO: www.cdc.gov/info

or visit the NIOSH website at www.cdc.gov/niosh.

For a monthly update on news at $\mathrm{NIOSH}$, subscribe to NIOSH eNews by visiting www.cdc.gov/niosh/eNews.

DHHS (NIOSH) Publication No. 2015-191

SAFER • HEALTHIER • PEOPLE ${ }^{\mathrm{TM}}$ 